\title{
Pacific (2020)
}

\author{
Laura Braid* and W.John Hopkins**
}

Unsurprisingly, 2020 was a year dominated in the Pacific by the regional and global responses to the novel coronavirus (COvID-19) pandemic. However, the impact on the Pacific was very specific to this diverse and unique region. As explored below, the impact upon the region exposed both the power of collective response, the weakness of the current disaster law frameworks and the fragility of the regional framework itself.

The Covid-19 Pandemic has tested the resilience and preparedness of disaster risk management (DRM) systems throughout the world. It has also highlighted variability in legal frameworks as well as the differential exposure and vulnerability that exists both between and within states. Nowhere is this clearer than in the Pacific where highly developed OECD member states rub shoulders with their vulnerable Small Island Developing counterparts. As a geographically huge region with limited health resources and weak social and economic infrastructure, the Pacific islands, in particular, are at significant risk from pandemics. This is well understood in a region where historic epidemics were devastating in their impact. The 1918 influenza pandemic for example, caused the death of around a quarter of Samoa's population, while a century later the 2019 measles epidemic caused 89 deaths.

In both cases the virus was imported from New Zealand (which in 1918 governed Samoa), emphasising the link between the metropolitan and island states, particularly in the field of Public Health. In both cases, it was New Zealand's failure to effectively manage the outbreaks that led to disastrous consequences for Samoa. However, COVID-19 has emphasised that it was not just the island states which are vulnerable to such outbreaks. Early modelling undertaken by the New Zealand Ministry of Health predicted that around

\footnotetext{
* Research Associate, LEAD Institute of Law, Emergencies and Disasters, Law School, University of Canterbury.

** Professor of Law, LEAD Institute of Law, Emergencies and Disasters, Law School, University of Canterbury.

*** The authors wish to acknowledge the assistance of Gabrielle Emery (IFRC Asia-Pacific Disaster Law Coordinator) in the preparation of this report. Any errors or omissions are those of the authors.
} 
27,0oo deaths could be expected in a worst-case scenario ${ }^{1}$ with ICU beds being overwhelmed in around 3 months. ${ }^{2}$

This vulnerability thus meant that an early response was essential and, as a consequence, national states of emergency were formally declared across the region. This enabled authorities to activate emergency powers and instigate strict border closures. This allowed the virus to largely be excluded from the region. The only exceptions in 2020 were the French territories (particularly French Polynesia) whose policy missteps led to a major outbreak (since contained) and Papua New Guinea whose porous border with West Papua (Indonesia) and significant governance challenges meant that the virus slowly gained a foothold in the latter part of 2020 .

The issue of multi-hazard response in the Pacific was brought to the fore in April, when four Pacific island states were hit by Tropical Cyclone Harold (with Fiji and Vanuatu being particularly affected), leading to what the UNICEF representative for the Pacific described as 'a disaster wrapped in a catastrophe inside a calamity'. ${ }^{3}$ The category 5 storm was one of the strongest ever recorded in the South Pacific and is a clear demonstration of the way a public health emergency can compound and multiply existing socio-economic and environmental threats. While Vanuatu was fortunate not to have any reported cases of coronavirus at the time (and has only recorded a single case to date), ${ }^{4}$ the challenges of delivering assistance when dual disasters strike was significant. For example, the impossibility of social distancing within community evacuation centres posed a particular health risk to vulnerable communities and risks compounding natural hazard risks. ${ }^{5}$ The experience of disasters in the Pacific over 2020 has thus highlighted the need to co-ordinate and integrate "traditional" DRM mechanisms, climate change response and public health systems.

1 Nick Wilson, 'Potential Worse Case Health Impacts from the COVID-19 Pandemic for New Zealand if Eradication Fails: Report to the NZ Ministry of Health', 24th March 202O, Wellington, <https://www.health.govt.nz/system/files/documents/publications/report_for _chief_science_advisor_-_health_-_24_march_final.pdf $>$ last accessed (as any subsequent URL) on 20 April 2021.

2 Nick Wilson, Lucy Telfar Barnard, Amanda Kvalsvig, and Michael Baker, 'Potential Health Impacts from the COVID-19 Pandemic for New Zealand if Eradication Fails: Report to the NZ Ministry of Health', 23rd March 202o, Wellington, <https://www.health.govt.nz/system/files/ documents/publications/report_for_moh_-_covid-19_pandemic_nz_final.pdf $>$.

3 See <https://time.com/5820382/coronavirus-cyclone-harold-vanuatu/>.

4 See $<$ https://www.worldometers.info/coronavirus/country/vanuatu/ $>$.

5 See further Jane McAdam, 'The twin calamities of climate change and COVID-19', available at <https://www.kaldorcentre.unsw.edu.au/publication/twin-calamities-climate -change-and-covid-19>. 
The geographical challenges of the Pacific region make it particularly vulnerable to logistics and transport challenges around the delivery of medical and humanitarian assistance (as well as other more "ordinary" supplies). The elimination of COVID-19 from most of the region meant that these issues, rather than the virus itself, became the main focus.

In March, Pacific Island Forum Foreign Ministers invoked the Biketawa Declaration to establish the Pacific Humanitarian Pathway on Covid-19 (PHP-C), a Pacific-led initiative which aimed to expedite forum members' requests for medical supplies, technical experts, and humanitarian assistance. ${ }^{6}$ The PHP-C was designed to coordinate existing humanitarian relationships with regional and international organisations and development partners. It specifically focused on establishing common regional protocols around the deployment of technical personnel; customs and biosecurity; immigration; repatriation of foreign nationals; and diplomatic clearances for aircraft and ships transporting medical or humanitarian assistance. ${ }^{7}$

A Ministerial Action group was established by the Forum Foreign Ministers, along with a Regional Task Force to oversee the implementation of the PHP-C. This was a significant development given the traditional emphasis on national sovereignty and bi-lateral links in the field of disaster management. The PHP-C thus represented an important shift in practical efforts to tackle DRM as a region, in line with the Boe Declaration and the Action Plan published in 2019. ${ }^{8}$ It is also significant that the response was Pacific Island-led, demonstrating the capacity for co-operation outside of the ambit of development partners (although the delivery of some PHP-C initiatives relied heavily upon external assistance).

One issue of particular significance for the Pacific Island states was the suspension of commercial air services, which created significant challenges for supply chains across the region. This gap was filled by the establishment of the Pacific Humanitarian Air Service which ensured that commercial flight suspensions did not impede the delivery of urgently required personnel, equipment and supplies.

6 See Pacific Heads of Health, 'Pacific Humanitarian Pathway on COVID-19' available at <https:/php.spc.int/sites/default/files/eventfiles/202O-07/2O2O\%2OPHoH\%2OTP2\%2oItem \%202.2\%20Pacific\%2oHumantarian\%2oPathway\%2ofor\%2oCOVID-19\%2O\%28PHP -C\%29.pdf>.

7 See further Pacific Islands Forum, 'Pacific Humanitarian Pathway on COVID-19 (PHP-C) Common Protocols', available at <https://www.forumsec.org/2020/08/04/20774/>.

8 Boe Declaration Action Plan, 2019 . 
At the international level, the UN OcHA sponsored Pacific Humanitarian Team released their Covid-19 Humanitarian Response Plan, which provided a framework for bilateral donors and partners to provide additional resources. ${ }^{9}$ In addition, the World Health Organisation (wHo) established a Pacific Joint Incident Management Team for Covid-19 (Joint IMT) based in Fiji, which brought together Ministries of Health across the Pacific and partners from other clusters through the och A Pacific Humanitarian Team. In May, the Joint IMT released the Pacific Action Plan for 2019 Novel Coronavirus (COVID-19) Preparedness and Response, under which partners coordinated activities 'to strengthen their health emergency preparedness.' ${ }^{10}$

Outside the example of CoviD-19, developments in the region included a new initiative by the United Nations Environment Programme (UNEP) to develop climate and ocean information services and multi-hazard early warning systems in a number of Pacific Island States, including the Cook Islands, Niue, Palau, the Republic of Marshall Islands and Tuvalu. ${ }^{11}$

\section{$3 \quad$ National Developments: Response and the Rule of Law}

As one would expect, the domestic developments in 2020 primarily focussed on response and recovery planning for the COVID-19 pandemic. The novel nature of the COVID-19 pandemic required a rethinking of domestic approaches to its containment (and eradication). In New Zealand this led to a hastily constructed but effective eradication policy, ${ }^{12}$ while in Australia, after a few early missteps and political conflicts between the states and Commonwealth, a largely effective strategy emerged. ${ }^{13}$ Across the Pacific Island states, legal responses were

$9 \quad$ Pacific Humanitarian Team, 'Pacific Humanitarian Team COVID-19 Response Plan', available at <https://reliefweb.int/sites/reliefweb.int/files/resources/PACIFIC\%2oHUMANI TARIAN\%2OCOVID-19_Appeal_Mayo720.pdf>.

10 See further <https://www.who.int/westernpacific/about/how-we-work/pacific-support/ news/detail/21-02-202O-pacific-steps-up-preparedness-against-covid-19>.

11 See further <https://reliefweb.int/report/world/new-unep-programme-support-climate -resilience-pacific-islands-through-early-warning $>$.

12 New Zealand Government, Ministry of Health, 'COVID-19: Elimination strategy for Aotearoa New Zealand', available at <https:/www.health.govt.nz/our-work/diseases -and-conditions/covid-19-novel-coronavirus/covid-19-response-planning/covid-19-elimi nation-strategy-aotearoa-new-zealand>.

13 Australian Government Department of Health, 'The Australian Health Sector Emergency Response Plan for Novel Coronavirus', available at <https://www.health.gov.au/resources/ publications/australian-health-sector-emergency-response-plan-for-novel-coronavirus -covid-19-short-form>. 
largely swift and effective with Fiji, ${ }^{14}$ Tonga, ${ }^{15}$ Samoa $^{16}$ and Vanuatu ${ }^{17}$ all producing COVID-19 response and recovery plans in the early part of 2020. In the latter case, following Cyclone Harold in April, the government of Vanuatu further released the Tropical Cyclone Harold Health Sector Response Plan, along with the CoviD-19 and Tropical Cyclone Harold Response Strategy. ${ }^{18}$ In July, the government released the Vanuatu Recovery Strategy 2020-2023 (Yumi Evriwan Tugeta) $\cdot{ }^{19}$ This strategy was of particular interest for its highlighting of the way in which a multi-hazard disaster 'blurred the lines between response, recovery and disaster risk reduction (preparedness and prevention)'. This has led to some re-thinking of disaster response in the region and consideration of greater cross-agency co-operation and a clearer leadership across multihazard and public health emergencies. ${ }^{20}$

Despite the impressive legal response from many Pacific Island states, the COVID-19 pandemic also highlighted the limited capacity of some Pacific island states to manage such emergencies. For example, Tuvalu's Ministry of Health requested a risk assessment from wHO in the early stages of the epidemic. This has since formed the basis for Tuvalu's public health preparedness and response efforts, in lieu of any formal domestic policies in place to respond to the pandemic.

However, some government responses have been met with public opposition. In June, Papua New Guinea passed the National Pandemic Act 2020, which introduced a new co-ordination mechanism through the National Control Centre along with several provisions relating to emergency response measures. These included travel restrictions, border surveillance, testing infrastructure

14 Fiji Ministry of Health and Medical Services, 'Fiji Coronavirus (COVID-19) Preparedness and Response Plan', available at <http://www.health.gov.fj/wp-content/uploads/202o/o8/ COVID-19-Fiji-Preparedness-and-Response-Plan-2020.pdf>.

15 Tonga Ministry of Health, 'COVID-19 Preparedness and Response Plan 2020', available at $<$ http://www.health.gov.to/en/ministry-health-national-covid-19-plan>.

16 Samoa Ministry of Healthy, 'Samoa COVID-19 Risk Communication and Community Engagement Strategic Plan - Preparedness Phase, available at $<$ https://www.health.gov .ws/projects/>.

17 See $<$ https://reliefweb.int/sites/reliefweb.int/files/resources/Vanuatu\%2oCOVID19\% 20SitRep1_20032020_1.pdf>.

18 Vanuatu Ministry of Health, 'Tropical Cyclone Harold Health Sector Response Plan', available at $<\mathrm{https}$ ://moh.gov.vu/images/TC-Harold/Response_Plan_10_April_202O_v3.pdf>.

19 Government of Vanuatu, 'Vanuatu Recovery Strategy 2020-2023, TC Harold \& COVID19 (Yumi Evriwan Tugeta)' available at <https://reliefweb.int/sites/reliefweb.int/files/ resources/tc_harold_and_covid-19_vanuatu_recovery_strategy_v3_130820.pdf > .

$20 \quad$ Ifrc Disaster Law, 'Disasters And Public Health Emergencies In The Pacific Project', see $<$ https://media.ifrc.org/ifrc/wp-content/uploads/sites/5/2020/11/Pacific-Disaster-Law-and -PHE-Snapshot.pdf>. 
and quarantine facilities. In addition, several emergency regulations were also issued to manage the CoviD-19 pandemic. ${ }^{21}$ However, opposition politicians have sought to challenge the new Act on the basis that it is unconstitutional. To some extent these criticisms have been supported by human rights organisations which have argued that the Act 'was rushed through parliament without adequate consultation with the opposition or civil society' and that it 'contains various provisions that could restrict human rights without adequate oversight'. ${ }^{22}$ The lack of confidence in the government in Papua New Guinea has exacerbated existing vulnerabilities and further undermined the pandemic response. This made an already difficult situation worse and as this article goes to press, there are significant concerns about the level of community spread in the PNG and the ability of the health authorities to cope with the expanding outbreak.

Similar concerns have been raised in the Solomon Islands where several strict COVID-19 emergency regulations were introduced. The Emergency Powers (COVID-19) Regulations (Nos. 1 \& 2) 2020 were issued in March and May respectively and allowed the Prime Minister to impose significant restrictions on the media; shut down any business deemed to be non-compliant with emergency orders; exempt foreign vessels from border closure and destroy illegal property. A third Emergency Powers (COVID-19) (No. 3) Regulation 2020 was issued in July under what was considered by some to be an unnecessarily prolonged state of emergency, subsequently extended for a further four months. Given that the Solomons have recorded no community cases, the extent of the legal response has been argued to be disproportionate to the reality of the pandemic in the islands. The opposition has once again raised concerns about the use of emergency powers (which removes parliament from the process) to resolve the crisis. In practice, 'once the governor general delegates those powers, parliament doesn't really have a role anymore and so there are no checks, balances and oversight being exercised. ${ }^{23}$ The opposition has called on new emergency legislation for the country to allow more effective response without the need for extraordinary powers. ${ }^{24}$

\footnotetext{
21 Emergency (General Provisions) (Covid-19) Act 2020; Emergency (General Provisions) (COVID-19) Regulation 2020; Emergency (Defence Force) (COVID-19) Act 2020.

22 See further <https://monitor.civicus.org/updates/2020/o8/25/new-png-pandemic-law -puts-rights-risk-while-groups-protest-against-mine-and-domestic-violence/>.

23 See <https://www.rnz.co.nz/international/pacific-news/422202/call-for-new-covid-19-emer gency-legislation-in-solomon-islands $>$.

24 See further <https://law.unimelb.edu.au/_data/assets/pdf_file/ooo6/34749o6/MF2o-Web1 -Solomons-Kekea-FINAL.pdf >.
} 
These challenges to the rule of law have become a feature of many of the emergency responses in Pacific Island states and is a matter of some concern. Some states, such as Samoa, have engaged in significant judicial reform in the midst of the crisis which has once again led to allegations that the crisis is being used to drive reforms that should be considered more fully in "normal" times. ${ }^{25}$ In this latter case, these actions have seen a rise in opposition to the ruling HRRP party and the first seriously contested election in Samoa for many years. ${ }^{26}$ These concerns were not unique to the island states, however. New Zealand's legal framework around pandemic response was also exposed, leading to the need for rushed legislation during the early part of the response phase and a partially successful court challenge. ${ }^{27}$

The above discussion should make it clear that despite the generally positive response to COVID-19 seen in the Pacific, all is not well in the world of Pacific disaster law. This is due less to the developments in the field (which were largely positive in 2020) but to the fragility of the regional framework itself and concerns around governance within states. A number of Pacific states have seen significant challenges to the rule of law during the pandemic and concerns have been raised about the use of the pandemic to challenge existing constitutional structures.

In addition, the generally impressive COVID response in 2020 must be contrasted with the dangerous clouds that have emerged on the Pacific regional horizon in the first few weeks of 2021. With the announcement in early 2021 that five of the sixteen member states of the Pacific Island Forum intend to leave the organisation, disaster law in the region faces a potential disaster of its own. Given that the Forum has been the key driver of regional co-operation in these fields, such a loss of legitimacy could seriously damage its effectiveness. Since these events occurred in 2021, they will be explored more fully in the 2021 update, when one must hope that a satisfactory resolution has been reached.

25 Kelly Buchanan, 'Samoa: Controversial Constitutional Reforms Passed', Global Legal Monitor, Library of Congress, 13 January 2021, available at <https://www.loc.gov/law/ foreign-news/article/samoa-controversial-constitutional-reforms-passed/>.

26 Lagipoiva Cherelle Jackson, 'Samoa's ruling party faces strongest election challenge in 20 years', The Guardian, 7 April 2021, available at <https://www.theguardian.com/world/2021/ apr/o8/samoa-election-2021-ruling-party-faces-strongest-election-challenge-in-20-years $>$.

27 John W Hopkins, 'Law, Luck and Lessons (Un)Learned: New Zealand Emergency Law from Canterbury to COVID-19' (2020) 31/4 Public Law Review, 371-375. 